\title{
A Convenient Synthesis of New Macrocyclic Naphthalenophanes ${ }^{\text {tr }}$
}

\author{
Hans-Friedrich Grützmacher* and Gerald Nolte \\ Lehrstuhl I für Organische Chemie der Fakultät für Chemie, Universität Bielefeld, \\ Postfach 100131, D-33501 Bielefeld, Germany
}

Received December 3, 1993

Key Words: Cyclophanes / Naphthalenophanes / McMurry reaction

The $(1,4)$ naphthalenophanes $6 \mathbf{a}, \mathbf{6} \mathbf{b}, \mathbf{7} \mathbf{a}$, and $\mathbf{7 b}$ were synthesized regiospecifically in two steps from the appropriate $\alpha, \omega-$ di-1-naphthylalkanes by a Friedel-Crafts acetylation of the two naphthalene groups followed by cyclization/dimeriza- tion of the resulting diketones by a McMurray reaction. The macrocyclic naphthalenophanes $6 \mathbf{a}$ and $\mathbf{6 b}$ exist in solution as a mixture of conformers while $\mathbf{7 a}$ and $\mathbf{7 b}$ were identified as the anti isomers.
Following the first report of the synthesis of a naphthalenophane in $1942^{[1]}$ the preparation and the properties of a large varity of cyclophanes containing condensed aromatic rings have been described ${ }^{[2]}$. The main interest was focussed on the interesting structures of these bridged aromatic hydrocarbons, the electronic interactions between the aromatic systems, and their deformation by the strain induced by short bridges. However, cyclophanes are also of interest as hosts in supramolecular chemistry exhibiting a hydrophobe cavity to encapsulate small molecules ${ }^{[2,3]}$. In this respect condensed arenophanes are of particular interest owing to their extended $\pi$-electron systems and the different shapes of the cages which can be constructed. Both properties are relevant for the complexation of guest ions or molecules. Therefore, we were interested to apply the McMurry methodology developed for the efficient synthesis of benzenocyclophanes ${ }^{[4]}$ to this class of compounds. A further prospect of a convenient synthesis of large amounts of condensed arenophanes is the possibility of a subsequent modification by suitable electrophilic substitution to alter the electronic properties of the cyclophane by the introduction of polar groups at the rim of the cavity. Here, we report on the productive synthesis of 1,2,20,21-tetramethyl[2.1.2.1] $(1,4)$ naphthalenophane-1,20-diene (6a), 1,2,21,22-tetramethyl[2.2.2.2](1,4)naphthalenophane-1,21-diene $(6 \mathbf{b})$, anti1,2-dimethyl[3.2](1,4)naphthalenophan-1-ene (7a), and anti1,2,5,15-tetramethyl[3.2](1,4)-naphthalenophan-1-ene (7b).

\section{Synthesis of the Naphtalenophanes}

The McMurry reaction ${ }^{[5]}$ provides an excellent access to the deoxygenated dimers of carbonyl compounds and alcohols in high yields. The availability of two suitable functional groups enables the preparation of even strained cyclic compounds ${ }^{[6]}$, and this method has been used before to synthesize macrocyclic cyclophanes ${ }^{[4,7]}$. Using high dilution techniques and working under controlled reaction conditions $^{[4]}$ to avoid polymerization we obtained the target cyclophanes in good yields, usually superior to a coupling by a Wittig reaction. Therefore, the naphthalenophanes 6 and 7 were prepared according to Scheme 1.
Di-1-naphthylmethane (4a) as a starting material was prepared by the reaction of 1-naphthylmagnesium bromide with methyl formiate in $\mathrm{THF}^{[\mathrm{ra}]}$ and reduction of the resulting secondary alcohol with $\mathrm{HI}^{[8 b]}$. Similarly, 1,2-di-1naphthylethane (4b) is readily available by coupling of 1(bromomethyl)naphthalene with magnesium. The yield is improved considerably $(78 \%)$ by modifying the method of Chandross and Dempster ${ }^{[9]}$ by using 5 mol- $\%$ of cuprous chloride and THF instead of diethyl ether. The syntheses of 1,3-di-1-naphthylpropane (4c) and 1,3-bis(2-methyl-1-naphthyl)propane (4d) are more elaborate ${ }^{[9]}$, but were achieved most conveniently as shown in Scheme 1 by condensation of ethyl 1-naphthylacetate (2a) and methyl (2-methyl-1naphthyl)acetate (2b), respectively, using isopropylmagnesium bromide as a strong base, followed by a WolffKishner reduction of the resulting bis(1-naphthylmethyl) ketones $\mathbf{3 a}$ and $\mathbf{3 b}$.

The diacetylation of the $\alpha, \omega-d i-1-n a p h t h y l a l k a n e s \quad 4 a-d$ was accomplished by reaction with 5-10 mol-\% excess of the acetyl chloride/AlCl ${ }_{3}$ complex in dichloromethane at $-16^{\circ} \mathrm{C}$ yielding $32-75 \%$ of the diacetyl derivatives $5 \mathbf{a}-\mathbf{d}$. The ${ }^{1} \mathrm{H}-\mathrm{NMR}$ spectra of $\mathbf{5 a}-\mathbf{d}$ proved a clean diacetylation in the $4,4^{\prime}$-positions of the naphthalene rings. The acetyl group exerts a low-field shift on the signals of $3-$ and $5-\mathrm{H}$ at the naphthalene rings to $\delta=7.78-7.84$ and $8.80-$ 8.84 , respectively. Hence, acetylation in other positions of the naphthalene rings and/or any triple or polyacetylation would have been detected reliably. The reductive coupling and dimerization of the diketones $\mathbf{5 a}$ and $\mathbf{5} \mathbf{b}$ by the McMurry reaction was achieved within three days under high dilution conditions, preparing the McMurry reagent in situ by the reduction of $\mathrm{TiCl}_{4}$ with $\mathrm{Zn}(\mathrm{Cu})$ in dimethoxyethane and carefully excluding any air by a stream of nitrogen. The macrocyclic cyclophanes 1,2,20,21-tetramethyl[2.1.2] $(1,4)$ naphthalenophan-1,20-diene $(6 \mathbf{6})$ and $1,2,21,22$ tetramethyl[2.2.2.2] (1,4)naphthalenophane-1,21-diene (6b) were obtained in a yield of 64 and $40 \%$, respectively. The formation of a monomeric small ring cyclophane by direct cyclization of 5a is not expected on steric reasons, but a 
Scheme 1
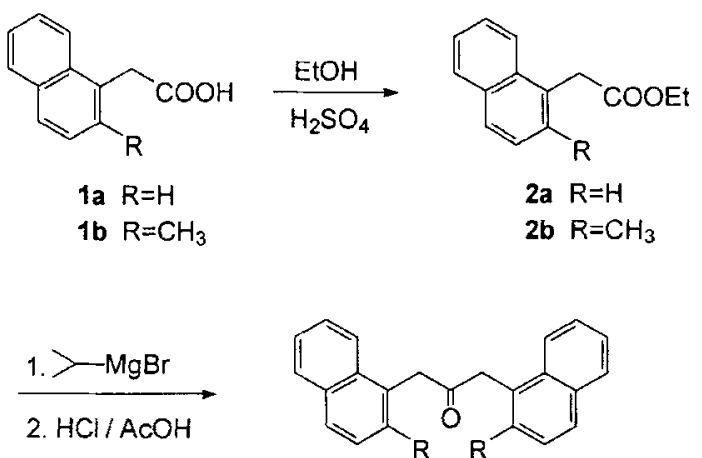<smiles>[R]c1ccc2ccccc2c1CC(=O)Cc1c([R])ccc2ccccc12</smiles>

3a $\mathrm{R}=\mathrm{H}$ 3b $\mathrm{R}=\mathrm{CH}_{3}$


4c $\mathrm{R}=\mathrm{H}$

4d $\mathrm{R}=\mathrm{CH}_{3}$
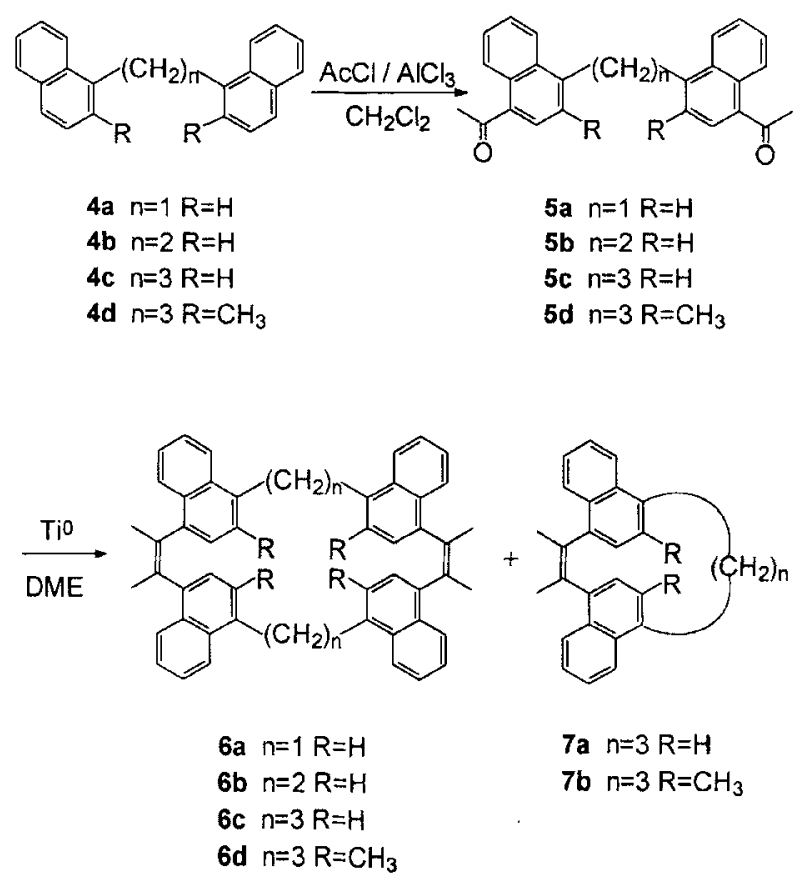

monomer was either not detected in the case of $\mathbf{5 b}$, where a direct cyclization to a [2.2](1,4)-naphthalenophane appears feasible. In contrast, the reductive coupling of $\mathbf{5 c}$ and $5 d$ under the same conditions afforded the monomeric coupling products 1,2-dimethyl[3.2](1,4)naphthalenophan-1-ene (7a) and 1,2,5,15-tetramethyl[3.2] $(1,4)$ naphthalenophan-1ene $(7 \mathbf{b})$ in a yield of 41 and $50 \%$, respectively, and only small amounts of the dimers $6 c$ and $6 d$ were detected by chromatography of the crude reaction product. In the case of 1,3-bis(4-acylphenyl)propanes the formation of mono- meric and dimeric coupling products could be controlled by the reaction conditions of the McMurry reaction, in particular by the rate of the addition of the diketone to the reagent mixture ${ }^{[4 a]}$. In the case of $\mathbf{5 c}$, however, decreasing the time for the addition of the diketone resulted primarily in the formation of polymers, although some dimeric coupling product $\mathbf{6 c}$ was observed besides $7 \mathbf{a}$ in the mass spectrum of the crude reaction product.

Compounds $6 \mathbf{a}, 7 \mathbf{a}$, and $7 \mathbf{b}$ dissolve easily in dichloromethane, chloroform, and acetone while $\mathbf{6 b}$ as well as $\mathbf{5 b}$ and $\mathbf{4 b}$ are almost insoluble in these solvents. Therefore, purification of $\mathbf{6 b}$ and $\mathbf{5 b}$ was difficult, and their elemental analysis revealed still some impurities. All naphthalenophanedienes and their solutions proved to be light-sensitive and showed a yellow discoloration after exposure to daylight for a few days. To examine the photoreactions of these compounds, a solution of $\mathbf{6 a}$ in cyclohexane was irradiated with UV light in a stream of air by using a catalytic amount of iodine ${ }^{[10,11]}$. A 2:1 mixture of anti- (8a) and syn-1,2,20,21tetramethyl[1.1](5.8)piceno[2](1,4)naphthalenophan-1-ene (8b) was isolated as the main reaction product (see Figure 1) and analyzed by ${ }^{1} \mathrm{H}-\mathrm{NMR}$ spectroscopy and mass spectrometry. The mass spectrum of the reaction product proved clearly by an appropriate mass shift of the molecular ion that cyclization and dehydrogenation had occurred only across one of the etheno bridges. The ${ }^{1} \mathrm{H}-\mathrm{NMR}$ spectrum reveals two signals of the olefinic methyl groups at $\delta=2.50$ and 2.44 which can be attributed to syn and anti conformers of $\mathbf{8 a} / \mathbf{b}$, respectively. The integration of the methyl group signals prove a syn/anti $1: 2$ ratio for the two conformers. A singlet at $\delta=6.83$ for the piceno $6-\mathrm{H}$ and $7-\mathrm{H}$ confirms an aromatization of only two of the four naphthalene rings of 6a. The synlanti orientation of the two naphthalene rings is indicated by two $\mathrm{AB}$ spin systems centered at $\delta=7.35$ (syn) and 7.00 (anti), respectively. Besides photocyclization and dehydrogenation an oxidation of $\mathbf{6 a}$ during the photolysis had occurred probably also because of the formation of some insoluble material during the photolysis.
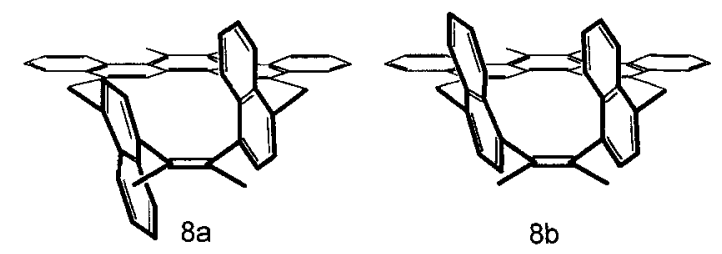

Figure 1. anti-(8a) and syn-1,2,20,21-tetramethyl[1.1](5,8)piceno[2]$(1,4)$ naphthalenophan-1-ene $(\mathbf{8 b})$

\section{${ }^{1} \mathrm{H}-\mathrm{NMR}$ - Spectra and Conformation of the Naphthalenophanes}

A $(Z)$ configuration at the $\mathrm{C}-\mathrm{C}$ double bond is expected for $6 \mathbf{a}$ and $\mathbf{6 b}$, but otherwise these macrocyclic naphthalenophanedienes should be rather flexible and should adopt conformations containing the various synlanti orientations of the naphthalene groups as shown schematically in Figure 2. 6a behaves as a single pure compound during thin-layer chromatography and EI mass spectrometry, but the ${ }^{1} \mathrm{H}$ - 
NMR spectrum reveals the presence of at least three conformers not interconverting on the NMR time scale. Thus, three signal groups are observed for the two adjacent protons $(2-\mathrm{H}$ and $3-\mathrm{H})$ at the substituted ring of the naphthalene unit: one intense $\mathrm{AB}$ spin system centered at $\delta=6.28$ and two weaker ones at $\delta=6.66$ and 6.68. The distinct high-field shift of the signals of these protons at the bridged ring of the naphthalene unit indicates a preferred anti orientation of opposite naphthalene rings of $6 \mathbf{a}$ which is present in the conformations $\mathbf{C}$ and $\mathbf{E}$ and partially also in $\mathbf{B}$ (Figure 2). The variable-temperature ${ }^{1} \mathrm{H}-\mathrm{NMR}$ spectra of $\mathbf{6 a}$ in tetrachlorodeuterioethane up to $100^{\circ} \mathrm{C}$ shows a coalescence for all signals, due to a flipping of the naphthalene rings. The coalescence temperatures $\left(T_{\mathrm{c}}\right)$ of the signals of the protons of the methyl substituent and of $6 / 7-\mathrm{H}, 5 / 8-\mathrm{H}$ and $2 /$ $3-\mathrm{H}$ at the naphthalene ring are $55,55,75$, and $85^{\circ} \mathrm{C}$, respectively. These $T_{\mathrm{c}}$ values correspond to $\Delta G^{\circ}=69.3 \pm 0.4$ $\mathrm{kJ} / \mathrm{mol}$ for the conformational change of $6 \mathbf{a}$. The coalescence of the signals of the protons at the methano bridge occurs around $100^{\circ} \mathrm{C}$ but was not determined specifically. The ${ }^{1} \mathrm{H}-\mathrm{NMR}$ spectrum obtained at $100^{\circ} \mathrm{C}$ exhibits a sharp singlet of the protons $2 / 3-\mathrm{H}$ at $\delta=6.50$, thus showing still a high-field shift. A similar shift $(\delta \approx 6.80)$ is observed for the protons at the benzene rings of 1,2,16,17-tetramethyl[2.1.2.1]paracyclophane-1,16-diene ${ }^{[4 \mathrm{c}]}$ and was attributed to an ,all-face-to-face" conformation of the benzene rings.

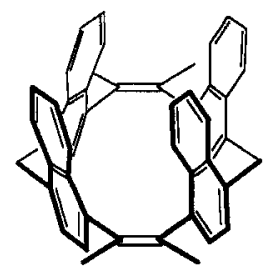

A

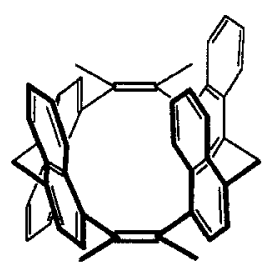

B

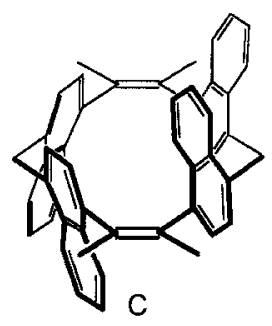

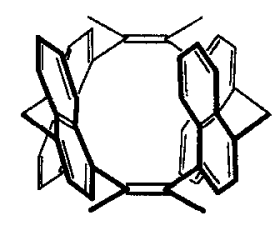

D

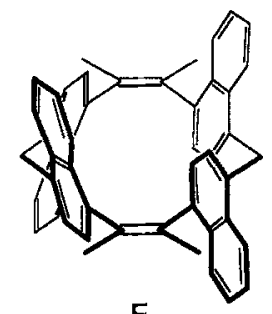

$E$
Figure 2. Possible conformations of 1,2,20,21-tetramethyl[2.1.2.1]$(1,4)$ naphthalenophane-1,20-diene $(\mathbf{6 a})$

The [2.2.2.2]naphthalenophane $\mathbf{6 b}$ exhibits a normal EI mass spectrum but is resolved into three components by chromatography (petroleum ether/ethyl acetate, 5:1). We failed in separating these components on a preparative scale, due to the small differences of the $R_{\mathrm{f}}$ values and the insufficient solubility of $\mathbf{6} \mathbf{b}$ in most organic solvents. The ${ }^{1} \mathrm{H}-\mathrm{NMR}$ spectrum of $\mathbf{6} \mathbf{b}$ corroborates the presence of at least three conformers. The two main components give rise to AB spin systems for the two adjacent protons at the substituted ring of the naphthalene groups centered at $\delta=6.55$ and 7.02, respectively, which is still indicative of an anti orientation of opposite naphthalene rings in these confor- mations but in a much more open structure than for $\mathbf{6 a}$. Heating the solution of $\mathbf{6 b}$ up to $100^{\circ} \mathrm{C}$ provides no effect in the ${ }^{1} \mathrm{H}-\mathrm{NMR}$ spectrum, showing that $\mathbf{6} \mathbf{b}$ is much less flexible than 6a. The addition of silver trifluoromethanesulfonate to a solution of the naphthalenophane $6 \mathbf{a}$ and $\mathbf{6 b}$ again does not change any signal in the ${ }^{1} \mathrm{H}-\mathrm{NMR}$ spectra. Therefore, $\mathbf{6 b}$ and $\mathbf{6 a}$ are unable in solution to serve as a host for $\mathrm{Ag}^{+}$ions.

Scheme 2

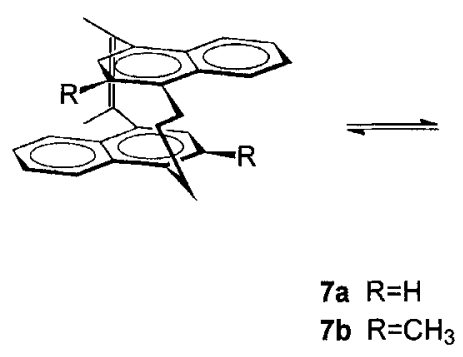

An examination of the ${ }^{1}$ H-NMR spectra of $7 \mathbf{a}$ and $\mathbf{7 b}$ shows clearly that these $[3.2](1,4)$ naphthalenophanes exist exclusively in the anti conformation (Scheme 2). For $\mathbf{7 a}$, only one $A B$ spin system at $\delta=5.80$ is observed for the two neighboring protons of the substituted ring of the naphthalene units, and similarly, the ${ }^{1} \mathrm{H}-\mathrm{NMR}$ spectrum of $7 \mathrm{~b}$ exhibits only a singlet at $\delta=5.81$ for the isolated protons at the naphthalene ring next to the bridge. In both cases the substantial high-field shift agrees with the staircase geometry of an anti conformation. The protons of the propano bridges give rise to two doublets of triplets for the terminal methylene groups centered at $\delta=3.32$ and 2.65 (for 7a), 3.30 and 2.94 (for $7 \mathbf{b}$ ). A quintet around $\delta=2.16$ (7a) and 2.25 (7b) is observed for the methylene group at the center. These signal pattern are characteristic of rather rigid [3.2]arenophanes. A fast interconversion of the enantiomeric anti conformers of $7 \mathbf{a}$ and $\mathbf{7 b}$ by ring flipping equilibrates the relative orientations of the two protons at the terminal methylene groups of the bridge and the two doublets of triplets would collap to a single triplet. It should be noted, however, that a wobble motion of the propano bridge only alters the relative orientations of these protons, but never makes them equivalent. In fact, the quintet observed for the protons of the central methylene groups agrees with a fast wobbling of the bridge. In line with this interpretation, a decrease of the temperature to $-90^{\circ} \mathrm{C}$ during the NMR measurement of $7 \mathbf{a}$ results in a splitting of each of the signals of $5-\mathrm{H}, 8-\mathrm{H}, 2-\mathrm{H}$, and $3-\mathrm{H}$ into two peaks and of 9-H into four peaks. The coalescent temperature for these signals is $-75^{\circ} \mathrm{C}$, corresponding to $\Delta G^{\circ}=$ $38.9 \mathrm{~kJ} / \mathrm{mol}$ at this temperature. For the analogous $1,2-\mathrm{di}-$ methyl[3.2]cyclophan-1-ene $\Delta G^{\circ}=47.5 \mathrm{kj} / \mathrm{mol}$ was observed for the wobbling of the propano bridge ${ }^{[4 a]}$.

The financial assistance by the Fonds der Chemischen Industrie is gratefully acknowledged. We thank Mr. K.-P. Mester for the determination of the ${ }^{1} \mathrm{H}-\mathrm{NMR}$ spectra and Mrs. B. Michel for performing the elemental analyses. 


\section{Experimental}

${ }^{1}$ H NMR: Bruker AM 300 (300 MHz), TMS as internal standard. - MS: Finnigan MAT CH5 and Fisons VG AutoSpec, direct insertion and fractional evaporation of the sample. - IR: PerkinElmer $840, \mathrm{KBr}$ pellet. - Melting points: Büchi 512, uncorrected. - Column chromatography: Merck silica gel 60 (70-230 mesh/ 0.063-0.200 mm). - PTLC: Silica gel on glass plates (Merck $F_{254}$ ). - Elemental analysis: Leco CHNS-932, microanalytical laboratory of the University of Bielefeld.

Di-1-naphthylmethane (4a was synthesized in two steps by the method of Schmidlin and Massini ${ }^{[8 a]}$ and of Blicke ${ }^{[8 b]}$.

1,2-Di-1-naphthylethane ${ }^{[9,12]}$ (4b): A mixture of $13.5 \mathrm{ml}(89.4$ $\mathrm{mmol}$ ) of 1-(bromomethyl)naphthalene and $2.70 \mathrm{~g}(111.1 \mathrm{mmol})$ of magnesium in $100 \mathrm{ml}$ of dry THF is refluxed for $20 \mathrm{~h}$. After cooling to room temp. and filtering from magnesium $11.0 \mathrm{ml}(72.8 \mathrm{mmol})$ of 1 -(chloromethyl)naphthalene and $445 \mathrm{mg}(4.5 \mathrm{mmol}$ ) of cuprous chloride are added to the solution. Heating is continued for $3 \mathrm{~h}$ followed by stirring at room temp. for $20 \mathrm{~h}$. The mixture is hydrolyzed with hydrochloric acid/water, and the aqueous layer is extracted with dichloromethane. The organic layers are collected, washed with a $\mathrm{NaHCO}_{3}$ solution, dried with $\mathrm{Na}_{2} \mathrm{SO}_{4}$, and the solvent is evaporated. The residue is diluted with hexane and the precipitate filtered and dried. Yield of $\mathbf{4 b} 7.32 \mathrm{~g}(58 \%)$. Colorless crystals, m.p. $160-161^{\circ} \mathrm{C}$ (ref. ${ }^{[9,12]} 161^{\circ} \mathrm{C}$ ). - IR $(\mathrm{KBr}): \tilde{v}=3065$ $\mathrm{cm}^{-1}, 3040,2941,2876,1595,1506,1463,1393,791,776 .-{ }^{1} \mathrm{H}$ NMR $\left(300 \mathrm{MHz}, \mathrm{CDCl}_{3}\right): \delta=8.12\left(\mathrm{dd},{ }^{3} J=7.7,{ }^{4} J=1.5 \mathrm{~Hz}\right.$; $2 \mathrm{H}, 8-\mathrm{H}), 7.88\left(\mathrm{dd},{ }^{3} J=7.4,{ }^{4} J=2.1 \mathrm{~Hz} ; 2 \mathrm{H}, 5-\mathrm{H}\right), 7.74(\mathrm{~d}, J=$ $8.0 \mathrm{~Hz} ; 2 \mathrm{H}, 2-\mathrm{H}$ ), 7.46-7.56 (dquint, ${ }^{3} J=7.6,{ }^{4} J=2.0 \mathrm{~Hz} ; 4 \mathrm{H}$, $6 / 7-\mathrm{H}$ ), 7.43-7.33 (dquint, ${ }^{3} J=8.0,{ }^{4} J=1.4 \mathrm{~Hz} ; 4 \mathrm{H}, 3 / 4-\mathrm{H}$ ), 3.51 (s, $4 \mathrm{H}, \mathrm{CH}_{2}$ ). - MS (EI, $\left.70 \mathrm{eV}\right), m / z(\%): 282\left[\mathrm{M}^{+}\right](20), 141(100)$, 115 (16), 142 (14). - MS $\left(\mathrm{C}_{22} \mathrm{H}_{18}\right)$; calcd. 282.14085, found 282.14105 .

1,3-Di-1-naphthyl-2-propanone (3a) ${ }^{[9]}: 32.45 \mathrm{~g}(152 \mathrm{mmol})$ of ethyl 1-naphthylacetate (2a) ${ }^{[13]}$ [prepared from 1-naphthylacetic acid (1a)] is added at $0^{\circ} \mathrm{C}$ to a solution of $18.5 \mathrm{ml}(197 \mathrm{mmol})$ of isopropyl bromide and $4.81 \mathrm{~g}(198 \mathrm{mmol})$ of magnesium in $120 \mathrm{ml}$ of diethyl ether. After stirring at room temp. for $2 \mathrm{~h}$, the solution is hydrolyzed with hydrochloric acid and extracted with diethyl ether. After evaporation of the solvent $250 \mathrm{ml}$ of glacial acetic acid and $110 \mathrm{ml}$ of $7 \mathrm{~N} \mathrm{HCl}$ are added to the residue, and the mixture is refluxed for $5 \mathrm{~h}$. The solution is neutralized with $\mathrm{NaOH} /$ $\mathrm{NaHCO}_{3}$ and extracted with dichloromethane. After recrystallization from ethanol colorless crystals are obtained. Yield of 3a 20.36 g $\left(80^{\%} \%\right.$ ), m.p. $108^{\circ} \mathrm{C}$ (ref. ${ }^{[9]} 109^{\circ} \mathrm{C}$ ). - IR $(\mathrm{KBr}): \tilde{v}=3042 \mathrm{~cm}^{-1}$, $3012,2902,1713,1598,1511,1418,1399,1332,1305,1077,1053$, $788,769 .-{ }^{1} \mathrm{H}$ NMR $\left(300 \mathrm{MHz}, \mathrm{CDCl}_{3}\right): \delta=7.86\left(\mathrm{dd},{ }^{3} J=8.8\right.$, $\left.{ }^{4} J=1.3 \mathrm{~Hz} ; 2 \mathrm{H}, 8-\mathrm{H}\right), 7.80(\mathrm{~d}, J=8.2 \mathrm{~Hz} ; 2 \mathrm{H}, 2-\mathrm{H}), 7.71(\mathrm{~d}$, $J=8.5 \mathrm{~Hz} ; 2 \mathrm{H}, 5-\mathrm{H}), 7.48\left(\mathrm{dt},{ }^{3} J=7.4,{ }^{4} J=1.2 \mathrm{~Hz} ; 2 \mathrm{H}, 7-\mathrm{H}\right)$, $7.42(\mathrm{dd}, J=7.0$ and $8.1 \mathrm{~Hz} ; 2 \mathrm{H}, 3-\mathrm{H}), 7.41\left(\mathrm{dt},{ }^{3} J=7.6,{ }^{4} J=\right.$ $1.4 \mathrm{~Hz} ; 2 \mathrm{H}, 6-\mathrm{H}), 7.29$ (d, $J=6.9 \mathrm{~Hz} ; 2 \mathrm{H}, 4-\mathrm{H}), 4.14(\mathrm{~s}, 4 \mathrm{H}$, $\mathrm{CH}_{2}$ ). - MS (EI, $\left.70 \mathrm{eV}\right), \mathrm{m} / \mathrm{z}(\%): 310\left[\mathrm{M}^{+}\right](22), 141(100), 115$ (28), 142 (23). $-\mathrm{C}_{23} \mathrm{H}_{18} \mathrm{O}$ (310.4): calcd. C 89.00, $\mathrm{H}$ 5.84; found C 88.93, H 5.99 .

1,3-Di-1-naphthylpropane $(4 \mathrm{c})^{[9]}: 4.87 \mathrm{~g}(15.7 \mathrm{mmol})$ of $3 \mathrm{a}, 3.23$ $\mathrm{g}(61.2 \mathrm{mmol})$ of a $80 \%$ aqueous hydrazine solution, and $4.56 \mathrm{~g}$ $(81.7 \mathrm{mmol})$ of sodium hydroxide in $45 \mathrm{ml}$ of diethylene glycol are heated to $120^{\circ} \mathrm{C}$. After $2 \mathrm{~h}$ the temp. of the bath is increased to $200^{\circ} \mathrm{C}$, and heating is continued for additional $6 \mathrm{~h}$ while the water/ hydrazine hydrate mixture is removed by distillation. After cooling the reaction mixture is extracted with dichloromethane, the solvent is evaporated and the residue recrystallized from ethanol. Colorless crystals, yield of 4 c $2.98 \mathrm{~g}\left(64 \%\right.$ ), m.p. $69^{\circ} \mathrm{C}$ (ref. ${ }^{[9]} 69^{\circ} \mathrm{C}$ ). - IR
$(\mathrm{KBr}): \tilde{v}=3073 \mathrm{~cm}^{-1}, 3050,2935,2866,2834,1596,1507,1452$, 1399, 1257, 1023, 792, 775. $-{ }^{1} \mathrm{H}$ NMR (300 MHz, $\left.\mathrm{CDCl}_{3}\right): \delta=$ $7.97(\mathrm{~m}, J=9.7 \mathrm{~Hz} ; 2 \mathrm{H}, 8-\mathrm{H}), 7.86(\mathrm{~m}, J=9.5 \mathrm{~Hz} ; 2 \mathrm{H}, 5-\mathrm{H})$, $7.74\left(\mathrm{dd},{ }^{3} \mathrm{~J}=7.7,{ }^{4} J=1.2 \mathrm{~Hz} ; 2 \mathrm{H}, 4-\mathrm{H}\right), 7.50-7.24(\mathrm{~m}, 8 \mathrm{H}, 2$ $3 / 6 / 7-\mathrm{H}$ ), 3.22 (t, $J=7.7 \mathrm{~Hz} ; 4 \mathrm{H}, \mathrm{CH}_{2} \mathrm{CH}_{2} \mathrm{CH}_{2}$ ), 2.25 (quint, $J=$ $\left.7.8 \mathrm{~Hz} ; 2 \mathrm{H}, \mathrm{CH}_{2} \mathrm{CH}_{2} \mathrm{CH}_{2}\right)$. - MS (EI, $\left.70 \mathrm{eV}\right), \mathrm{m} / \mathrm{z}(\%): 296\left[\mathrm{M}^{+}\right]$ (92), 142 (100), 141 (88), 155 (79), 154 (77), 153 (33), 297 (28).

Ethyl (2-Methyl-1-naphthyl)acetate (2b) ${ }^{[13]}$ : A solution of 14.02 $\mathrm{g}(77.4 \mathrm{mmol})$ of (2-methyl-1-naphthyl)acetonitrile ${ }^{[14]}, 100 \mathrm{ml}$ of methanol, and $15 \mathrm{ml}$ of concd. sulfuric acid is refluxed for $36 \mathrm{~h}$. The methanol is removed by distillation and the remaining mixture poured into $200 \mathrm{ml}$ of ice/water. After extraction with dichloromethane the residue is distilled to yield $12.9 \mathrm{~g}(77 \%)$ of $\mathbf{2 b}$, b.p. $115^{\circ} \mathrm{C} / 0.8$ mbar. - IR $(\mathrm{KBr}): \tilde{v}=3056 \mathrm{~cm}^{-1}, 2955,1731,1513$, $1434,1327,1261,1199,1155,1038,810,741 .{ }^{-1}$ H NMR $(300$ $\left.\mathrm{MHz}, \mathrm{CDCl}_{3}\right): \delta=7.99(\mathrm{dd}, J=8.3 \mathrm{~Hz} ; 1 \mathrm{H}, 8-\mathrm{H}), 7.78(\mathrm{dd}, J=$ $7.8 \mathrm{~Hz} ; 1 \mathrm{H}, 5-\mathrm{H}), 7.68(\mathrm{~d}, J=8.3 \mathrm{~Hz} ; 1 \mathrm{H}, 3-\mathrm{H}), 7.49(\mathrm{dt}, J=6.9$ $\mathrm{Hz} ; 1 \mathrm{H}, 6 / 7-\mathrm{H}), 7.40(\mathrm{dt}, J=7.7 \mathrm{~Hz} ; 1 \mathrm{H}, 6 / 7-\mathrm{H}), 7.31(\mathrm{~d}, J=8.4$ $\mathrm{Hz} ; 1 \mathrm{H}, 4-\mathrm{H}), 4.01\left(\mathrm{~s}, 2 \mathrm{H}, \mathrm{CH}_{2}\right), 3.64\left(\mathrm{~s}, 3 \mathrm{H}, \mathrm{OCH}_{3}\right), 2.53(\mathrm{~s}, 3 \mathrm{H}$, aromatic $\left.\mathrm{CH}_{3}\right),-\mathrm{MS}(\mathrm{EI}, 70 \mathrm{eV}), \mathrm{m} / z(\%): 214\left[\mathrm{M}^{+}\right](38), 155$ (100), 93 (24), 154 (21). - $\mathrm{C}_{14} \mathrm{H}_{14} \mathrm{O}_{2}$ (214.3): calcd. C 78.78, H 6.59 ; found $\mathrm{C} 78.50, \mathrm{H} 6.55$.

1,3-Bis(2-methyl-1-naphthyl)propane (4d) is prepared by the same procedure as $\mathbf{4 c}$, starting with $15.12 \mathrm{~g}(70.6 \mathrm{mmol})$ of $\mathbf{2 b}$. Yield $2.70 \mathrm{~g}(23 \%)$ recrystallized from ethanol.

3b: Colorless crystals, m.p. $156-158^{\circ} \mathrm{C}$. - IR $(\mathrm{KBr}): \tilde{v}=3052$ $\mathrm{cm}^{-1}, 2923,2864,1705,1599,1513,805,737 .{ }^{1} \mathrm{H}$ NMR $(300$ $\left.\mathrm{MHz}, \mathrm{CDCl}_{3}\right): \delta=7.81\left(\mathrm{dd},{ }^{3} \mathrm{~J}=8.3,{ }^{4} \mathrm{~J}=2.7 \mathrm{~Hz} ; 2 \mathrm{H}, 8-\mathrm{H}\right), 7.71$ $(\mathrm{d}, J=8.4 \mathrm{~Hz} ; 2 \mathrm{H}, 4-\mathrm{H}), 7.64\left(\mathrm{dd},{ }^{3} J=7.0,{ }^{4} J=2.5 \mathrm{~Hz} ; 2 \mathrm{H}, 5-\right.$ $\mathrm{H}), 7.41(\mathrm{dt}, 2 \mathrm{H}, 6 / 7-\mathrm{H}), 7.37(\mathrm{dt}, 2 \mathrm{H}, 6 / 7-\mathrm{H}), 7.32(\mathrm{~d}, J=8.4 \mathrm{~Hz}$; $2 \mathrm{H}, 3-\mathrm{H}), 4.19\left(\mathrm{~s}, 4 \mathrm{H}, \mathrm{CH}_{2}\right), 2.35\left(\mathrm{~s}, 6 \mathrm{H}, \mathrm{CH}_{3}\right)$. - MS (EI, $\left.70 \mathrm{eV}\right)$, $m / z$ (\%): $338\left[\mathrm{M}^{+}\right](14), 155(100), 156(22), 153(14),-\mathrm{C}_{25} \mathrm{H}_{22} \mathrm{O}$ (338.4): calcd. C 88.72, H 6.56; found C 88.77, H 6.60 .

4d: The residue is recrystallized from acetone, yield $1.14 \mathrm{~g}(44 \%)$. Colorless crystals, m.p. $71^{\circ} \mathrm{C}$. - IR $(\mathrm{KBr}): \tilde{\mathrm{v}}=3040 \mathrm{~cm}^{-1}, 2940$, $2860,1595,1515,1380,1175,1025,805,778,735$ - ' H NMR $(300$ $\left.\mathrm{MHz}, \mathrm{CDCl}_{3}\right): \delta=7.92\left(\mathrm{dd},{ }^{3} J=7.9 \mathrm{~Hz} ; 2 \mathrm{H}, 8-\mathrm{H}\right), 7.75\left(\mathrm{dd},{ }^{3} J=\right.$ $\left.8.4,{ }^{4} J=2.0 \mathrm{~Hz} ; 2 \mathrm{H}, 5-\mathrm{H}\right), 7.58(\mathrm{~d}, J=8.4 ; 2 \mathrm{H}, 4-\mathrm{H}), 7.40(\mathrm{dt}$, $\left.{ }^{3} J=6.8,{ }^{4} J=1.7 \mathrm{~Hz} ; 2 \mathrm{H}, 6 / 7-\mathrm{H}\right), 7.35\left(\mathrm{dt},{ }^{3} J=6.9,{ }^{4} J=1.4 \mathrm{~Hz}\right.$; $2 \mathrm{H}, 6 / 7-\mathrm{H}), 7.25(\mathrm{~d}, J=8.4 \mathrm{~Hz} ; 2 \mathrm{H}, 3-\mathrm{H}), 3.23(\mathrm{t}, J=8.0 \mathrm{~Hz}$; $\left.4 \mathrm{H}, \mathrm{CH}_{2} \mathrm{CH}_{2} \mathrm{CH}_{2}\right), 2.45\left(\mathrm{~s}, 6 \mathrm{H}, \mathrm{CH}_{3}\right), 1.98\left(\mathrm{~m}, 2 \mathrm{H}, \mathrm{CH}_{2} \mathrm{CH}_{2} \mathrm{CH}_{2}\right)$. - MS (EI, $70 \mathrm{eV}), m / z(\%): 324\left[\mathrm{M}^{+}\right](32), 155(100), 169(48), 153$ (38), 156 (34), 154 (29), 152 (24), 168 (24). $-\mathrm{C}_{25} \mathrm{H}_{24}$ (324.5): calcd. C 92.54, H 7.46; found C 92.52, H 7.37.

General Procedure for the Friedel-Crafts Acetylation of $\mathbf{4 a - d : ~ A ~}$ solution of $42 \mathrm{mmol}$ of the respective di-1-naphthylalkane in $90 \mathrm{ml}$ of dry dichloromethane is added rapidly at $-16^{\circ} \mathrm{C}$ to a solution of

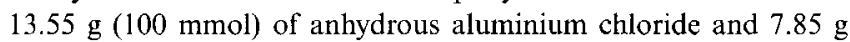
$(100 \mathrm{mmol})$ of acetyl chloride in $140 \mathrm{ml}$ of dry dichloromethane. After stirring for $1 \mathrm{~h}$ at $20^{\circ} \mathrm{C}$ the mixture is poured into $350 \mathrm{ml}$ of ice/water and extracted with dichloromethane. The extract is washed with water, dried with $\mathrm{Na}_{2} \mathrm{SO}_{4}$, and the solvent is evaporated under reduced pressure. The following substances are prepared by this method:

Bis(4-acetyl-1-naphthyl)methane (5a): The residue is recrystallized from acetone. Yield $7.85 \mathrm{~g}(53 \%)$. Colorless crystals, m.p. $192^{\circ} \mathrm{C}$. - IR (KBr): $\tilde{v}=3075 \mathrm{~cm}^{-1}, 2923,1667,1591,1575,1513$, $1458,1424,1348,1211,1191,821,771,762 .{ }^{1} \mathrm{H}$ NMR $(300 \mathrm{MHz}$, $\left.\mathrm{CDCl}_{3}\right): \delta=8.84\left(\mathrm{dd},{ }^{3} J=8.7,{ }^{4} \mathrm{~J}=1.0 \mathrm{~Hz} ; 2 \mathrm{H}, 5-\mathrm{H}\right), 8.03(\mathrm{dd}$, $\left.{ }^{3} J=7.8,{ }^{4} J=0.6 \mathrm{~Hz} ; 2 \mathrm{H}, 8-\mathrm{H}\right), 7.78(\mathrm{~d}, J=7.5 \mathrm{~Hz} ; 2 \mathrm{H}, 3-\mathrm{H})$, $7.63\left(\mathrm{dt},{ }^{3} J=8.7,{ }^{4} \mathrm{~J}=1.2 \mathrm{~Hz} ; 2 \mathrm{H}, 6-\mathrm{H}\right), 7.53\left(\mathrm{dt},{ }^{3} \mathrm{~J}=8.4,{ }^{4} J=\right.$ $1.4 \mathrm{~Hz} ; 2 \mathrm{H}, 7-\mathrm{H}), 7.07$ (d, $J=7.4 \mathrm{~Hz} ; 2 \mathrm{H}, 2-\mathrm{H}), 4.92(\mathrm{~s}, 2 \mathrm{H}$, 
$\left.\mathrm{CH}_{2}\right), 2.71\left(\mathrm{~s}, 6 \mathrm{H}, \mathrm{CH}_{3}\right) .-\mathrm{MS}(\mathrm{EI}, 70 \mathrm{eV}), \mathrm{m} / \mathrm{z}(\%): 352\left[\mathrm{M}^{+}\right]$ (73), 337 (100), 43 (75), 265 (48), 338 (28), 132 (22), 266 (21), 139 (21), 353 (21). $-\mathrm{C}_{25} \mathrm{H}_{20} \mathrm{O}_{2}$ (352.4): calcd. C 85.20, H 5.72; found C 85.22 , H 5.77

1,2-Bis (4-acetyl-1-naphthyl)ethane $(\mathbf{5 b})$ : The raw product is purified by heating with acetone. Yield $11.54 \mathrm{~g}(75 \%)$. Colorless crystals, m.p. $237-241^{\circ} \mathrm{C}$ (dec.). - IR (KBr): $\tilde{v}=3048 \mathrm{~cm}^{-1}, 2999$, $2948,2897,1667,1587,1574,1513,1465,1457,1424,1354,846$, 764. $-{ }^{1} \mathrm{H}$ NMR $\left(300 \mathrm{MHz}, \mathrm{CDCl}_{3}\right): \delta=8.84\left(\mathrm{dd},{ }^{3} J=7.6,{ }^{4} \mathrm{~J}=\right.$ $1.9 \mathrm{~Hz} ; 2 \mathrm{H}, 5-\mathrm{H}), 8.14\left(\mathrm{dd},{ }^{3} J=7.9,{ }^{4} J=1.8 \mathrm{~Hz} ; 2 \mathrm{H}, 8-\mathrm{H}\right), 7.83$ (d, $J=7.4 \mathrm{~Hz} ; 2 \mathrm{H}, 3-\mathrm{H}$ ), 7.63 (dquint, $J=7.6 \mathrm{~Hz} ; 4 \mathrm{H}, 6 / 7-\mathrm{H}$ ), $7.25(\mathrm{~d}, J=7.4 \mathrm{~Hz} ; 2 \mathrm{H}, 2-\mathrm{H}), 3.57\left(\mathrm{~s}, 4 \mathrm{H}, \mathrm{CH}_{2}\right), 2.74(\mathrm{~s}, 6 \mathrm{H}$, $\mathrm{CH}_{3}$ ). - MS (EI, $\left.70 \mathrm{eV}\right), m / z(\%): 366\left[\mathrm{M}^{+}\right](52), 183(100), 155$ (49), 140 (19), 184 (19), 139 (15), 367 (14). - MS $\left(\mathrm{C}_{26} \mathrm{H}_{22} \mathrm{O}_{2}\right)$ : calcd. 366.16198 , found 366.16317 .

1,3-Bis (4-acetyl-1-naphthyl) propane (5c): The crude product is recrystallized from acetone. Yield $12.46 \mathrm{~g}(78 \%)$. Colorless crystals, m.p. $98^{\circ} \mathrm{C}$. $-\mathrm{IR}(\mathrm{KBr}): \tilde{v}=3044 \mathrm{~cm}^{-1}, 3006,2950,2875,1681$, $1666,1590,1578,1514,1466,1457,1425,1349,1282,1245,1190$, $1116,831,812,768 .-{ }^{1} \mathrm{H}$ NMR $\left(300 \mathrm{MHz}, \mathrm{CDCl}_{3}\right): \delta=8.80(\mathrm{dd}$, $\left.{ }^{3} J=8.8,{ }^{4} J=1.1 \mathrm{~Hz} ; 2 \mathrm{H}, 5-\mathrm{H}\right), 7.97\left(\mathrm{dd},{ }^{3} J=8.8,{ }^{4} J=1.0 \mathrm{~Hz}\right.$; $2 \mathrm{H}, 8-\mathrm{H}), 7.84(\mathrm{~d}, J=7.4 \mathrm{~Hz} ; 2 \mathrm{H}, 3-\mathrm{H}), 7.58\left(\mathrm{dt},{ }^{3} J=6.9,{ }^{4} J=\right.$ $1.3 \mathrm{~Hz} ; 2 \mathrm{H}, 6-\mathrm{H}), 7.49\left(\mathrm{dt},{ }^{3} J=6.8,{ }^{4} J=1.4 \mathrm{~Hz} ; 2 \mathrm{H}, 7-\mathrm{H}\right), 7.34$ (d, $J=7.4 \mathrm{~Hz} ; 2 \mathrm{H}, 2-\mathrm{H}), 3.22\left(\mathrm{t}, J=7.6 \mathrm{~Hz} ; 4 \mathrm{H}, \mathrm{CH}_{2} \mathrm{CH}_{2} \mathrm{CH}_{2}\right.$ ), $2.71\left(\mathrm{~s}, 6 \mathrm{H}, \mathrm{CH}_{3}\right), 2.23$ (quint, $J=7.6 \mathrm{~Hz} ; 2 \mathrm{H}, \mathrm{CH}_{2} \mathrm{CH}_{2} \mathrm{CH}_{2}$ ). MS (EI, $70 \mathrm{eV}), m / z(\%): 380\left[\mathrm{M}^{+}\right](100), 365(78), 141(56), 175$ (50), 153 (48), 184 (48), 197 (40). $-\mathrm{C}_{27} \mathrm{H}_{24} \mathrm{O}_{2}$ (380.5): calcd. $\mathrm{C}$ 85.23, H 6.36; found C 85.29, H 6.40 .

1,3-Bis(4-acetyl-2-methyl-1-naphthyl)propane (5d): The raw material is purified by chromatography over silica gel (dichlormethane), followed by recrystallization from acetone. Yield $5.66 \mathrm{~g} \mathrm{(33 \% ).}$ Colorless crystals, m.p. $106-110^{\circ} \mathrm{C}$. $-\mathrm{IR}(\mathrm{KBr}): \tilde{v}=3082 \mathrm{~cm}^{-1}$, $3053,2967,2866,1660,1594,1572,1511,1350,1283,1246,1178$, $1156,1037,1012,881,760 .-{ }^{1} \mathrm{H}$ NMR $\left(300 \mathrm{MHz}, \mathrm{CDCl}_{3}\right): \delta=$ $8.71\left(\mathrm{dd},{ }^{3} J=7.7,{ }^{4} J=2.1 \mathrm{~Hz} ; 2 \mathrm{H}, 5-\mathrm{H}\right), 7.97\left(\mathrm{dd},{ }^{3} J=7.7,{ }^{4} \mathrm{~J}=\right.$ $2.0 \mathrm{~Hz} ; 2 \mathrm{H}, 8-\mathrm{HI}), 7.74(\mathrm{~s}, 2 \mathrm{H}, 3-\mathrm{H}), 7.52\left(\mathrm{dt},{ }^{3} \mathrm{~J}=6.8,{ }^{4} \mathrm{~J}=1.6\right.$ $\mathrm{Hz} ; 2 \mathrm{H}, 6-\mathrm{H}), 7.47\left(\mathrm{dt},{ }^{3} J=6.8,{ }^{4} J=1.7 \mathrm{~Hz} ; 2 \mathrm{H}, 7-\mathrm{H}\right), 3.28(\mathrm{t}$, $\left.J=8.2 \mathrm{~Hz} ; 4 \mathrm{H}, \mathrm{CH}_{2} \mathrm{CH}_{2} \mathrm{CH}_{2}\right), 2.72\left(\mathrm{~s}, 6 \mathrm{H}\right.$, acetylic $\left.\mathrm{CH}_{3}\right), 2.52(\mathrm{~s}$, $6 \mathrm{H}$, aromatic $\left.\mathrm{CH}_{3}\right), 1.99\left(\mathrm{~m}, 2 \mathrm{H}, \mathrm{CH}_{2} \mathrm{CH}_{2} \mathrm{CH}_{2}\right),-\mathrm{MS}(\mathrm{EI}, 70$ $\mathrm{eV}), m / z(\%): 408\left[\mathrm{M}^{+}\right](58), 43(100), 211$ (65), 153 (44), 393 (44), 197 (43), 169 (42), 189 (37), 152 (35). $-\mathrm{C}_{29} \mathrm{H}_{28} \mathrm{O}_{2}$ (408.5): calcd. C 85.26, H 6.91; found C 85.29, H 6.91.

General Procedure for the McMurry Coupling of $\mathbf{5} \mathbf{a}-\mathbf{d}^{[15]}: 11.3$ $\mathrm{ml}(103.0 \mathrm{mmol})$ of titanium tetrachloride is slowly added with stirring at $0^{\circ} \mathrm{C}$ to $200 \mathrm{ml}$ of dry dimethoxyethane (DME) in a stream of nitrogen by using an apparatus for high dilution. After stirring for additional $20 \mathrm{~min} 13.47 \mathrm{~g}(206.0 \mathrm{mmol})$ of $\mathrm{Zn} / \mathrm{Cu}$ couple is added in small portions. The blue-violet mixture is refluxed for 2 $\mathrm{h}$, then a solution of $4.31 \mathrm{mmol}$ of the respective diketone $5 \mathrm{a}-\mathbf{d}$ in $100 \mathrm{ml}$ of dry DME is added continuously within $72 \mathrm{~h}$ followed by refluxing of the mixture for additonal $12 \mathrm{~h}$. After cooling to room temp. the precipitate is filtered and washed with dichloromethane. The solvent is evaporated from the filtrate under reduced pressure, and the residue is treated with $200 \mathrm{ml}$ of $2 \mathrm{~N} \mathrm{HCl}$. The acidic solution is extracted five times with dichloromethane. The combined organic solutions are washed with water, dried with $\mathrm{Na}_{2} \mathrm{SO}_{4}$, and concentrated under reduced pressure. The crude cyclophanes obtained are purified by chromatography (silica gel, eluant hexane). By this method the following naphthalenophanes are synthesized:

1,2,20,21-Tetramethyl $[2.1 .2 .1](1,4)$ naphthalenophane-1,20-diene (6a): The product is recrystallized from acetone/ethanol. Yield 0.88 g (64\%). Colorless crystals, m.p. $210^{\circ} \mathrm{C}$ (dec.). - IR (KBr): $\tilde{v}=$
$3436 \mathrm{~cm}^{-1}, 3074,3040,2969,2913,2875,1589,1513,1445,1423$, $1390,1159,1089,1032,845,831,766,756 .-{ }^{1} \mathrm{H}$ NMR $(300 \mathrm{MHz}$, $\left.\mathrm{CDCl}_{3}, 20^{\circ} \mathrm{C}\right): \delta=8.00-8.15(\mathrm{~m}, 5.4 \mathrm{H}, 5 / 8-\mathrm{H}), 7.79(\mathrm{~d}, J=8.4$ $\mathrm{Hz} ; 1.0 \mathrm{H}, 5 / 8-\mathrm{H}), 7.40-7.60(\mathrm{~m}, 8.1 \mathrm{H}, 5 / 6 / 7 / 8-\mathrm{H}), 7.05(\mathrm{t}, J=7.6$ $\mathrm{Hz} ; 1.0 \mathrm{H}, 6 / 7-\mathrm{H}), 6.91(\mathrm{t}, J=7.6 \mathrm{~Hz} ; 0.6 \mathrm{H}, 6 / 7-\mathrm{H}), 6.78(\mathrm{~d}, J=$ $7.3 \mathrm{~Hz} ; 0.8 \mathrm{H}, 2 / 3-\mathrm{H}), 6.66(\mathrm{~d}, J=7.3 \mathrm{~Hz} ; 1.4 \mathrm{H}, 2 / 3-\mathrm{H}), 6.60(\mathrm{~d}$, $J=7.2 \mathrm{~Hz} ; 0.4 \mathrm{H}, 2 / 3-\mathrm{H}), 6.42(\mathrm{~d}, J=7.2 \mathrm{~Hz} ; 0.4 \mathrm{H}, 2 / 3-\mathrm{H}), 6.28$ (AB system, $J=7.3 \mathrm{~Hz} ; 4.4 \mathrm{H}, 2 / 3-\mathrm{H}), 6.00(\mathrm{~d}, J=7.2 \mathrm{~Hz} ; 0.3 \mathrm{H}$, 2/3-H), $5.27(\mathrm{~d}, J=7.2 \mathrm{~Hz} ; 0.3 \mathrm{H}, 2 / 3-\mathrm{H}), 5.10\left(\mathrm{~d},{ }^{2} J=14.9 \mathrm{~Hz}\right.$; $\left.0.3 \mathrm{H}, \mathrm{CH}_{2}\right), 4.90\left(\mathrm{dd},{ }^{2} J=14.8\right.$ and $\left.18.0 \mathrm{~Hz} ; 1.0 \mathrm{H}, \mathrm{CH}_{2}\right), 4.54(\mathrm{~s}$, $\left.1.6 \mathrm{H}, \mathrm{CH}_{2}\right), 4.15\left(\mathrm{~d},{ }^{2} J=18.0 \mathrm{~Hz} ; 0.3 \mathrm{H}, \mathrm{CH}_{2}\right), 3.85\left(\mathrm{dd},{ }^{2} J=\right.$ 15.8 and $\left.15.8 \mathrm{~Hz} ; 0.7 \mathrm{H}, \mathrm{CH}_{2}\right), 2.46\left(\mathrm{~s}, 5.2 \mathrm{H}, \mathrm{CH}_{3}\right), 2.37(\mathrm{~s}, 6.8 \mathrm{H}$, $\left.\mathrm{CH}_{3}\right) .-{ }^{1} \mathrm{H}$ NMR $\left(300 \mathrm{MHz}, \mathrm{Cl}_{2} \mathrm{DC}-\mathrm{CDCl}_{2}, 100^{\circ} \mathrm{C}\right): \delta=7.84$ $(\mathrm{m}, 5 / 8-\mathrm{H}), 7.19(\mathrm{~m}, 6 / 7-\mathrm{H}), 6.50(\mathrm{~s}, 2 / 3-\mathrm{H}), 2.41\left(\mathrm{~s}, \mathrm{CH}_{3}\right) . \mathrm{MS}$ (EI, $70 \mathrm{eV}), m / z(\%): 640\left[\mathrm{M}^{+}\right](100), 641(64), 319(41), 303(36)$, 169 (35), 305 (33), 289 (29). - MS $\left(\mathrm{C}_{50} \mathrm{H}_{40}\right)$ : calcd. 640.31300, found 640.31456 . $-\mathrm{C}_{50} \mathrm{H}_{40}(640.9)$ : calcd. C 93.71, H 6.29; found C 92.52, H 6.59 .

1,2,21,22-Tetramethyl[2.2.2.2](1,4) naphthalenophane-1,21-diene (6b): The crude product is purified by heating with acetone. Yield $0.58 \mathrm{~g}(40 \%)$. Colorless crystals, m.p. $>360^{\circ} \mathrm{C}$ (dec.). $-\mathrm{IR}(\mathrm{KBr})$ : $\tilde{\mathrm{v}}=3068 \mathrm{~cm}^{-1}, 2929,2856,1591,1511,1448,1421,1389,1224$, $1154,1088,1033,827,760 .-{ }^{1} \mathrm{H}$ NMR $\left(300 \mathrm{MHz}, \mathrm{CDCl}_{3}\right): \delta=$ $8.19-7.83(\mathrm{~m}, 8 \mathrm{H}, 5 / 8-\mathrm{H}), 7.66-7.41(\mathrm{~m}, 8 \mathrm{H}, 6 / 7-\mathrm{H}), 7.24(\mathrm{~m}, 3 \mathrm{H}$ $2 / 3-\mathrm{H}), 7.01(\mathrm{~d}, J=7.4 \mathrm{~Hz} ; 1.3 \mathrm{H}, 2 / 3-\mathrm{H}), 6.79(\mathrm{~d}, J=7.4 \mathrm{~Hz}$; $1.8 \mathrm{H}, 2 / 3-\mathrm{H}), 6.62(\mathrm{~d}, J=7.4 \mathrm{~Hz} ; 1.3 \mathrm{H}, 2 / 3-\mathrm{H}), 6.48(\mathrm{~d}, J=7.4$ $\mathrm{Hz} ; 0.6 \mathrm{H}, 2 / 3-\mathrm{H}), 3.95\left(\mathrm{~d},{ }^{2} J=15.2 \mathrm{~Hz} ; 0.9 \mathrm{H}, \mathrm{CH}_{2}\right), 3.87\left(\mathrm{~d},{ }^{2} J=\right.$ $\left.14.5 \mathrm{~Hz} ; 0.6 \mathrm{H}, \mathrm{CH}_{2}\right), 3.73-3.60\left(2 \mathrm{~d}, 1.7 \mathrm{H}, \mathrm{CH}_{2}\right), 3.50-3.35(2$ d, $\left.1.7 \mathrm{H}, \mathrm{CH}_{2}\right), 3.29\left(\mathrm{~d},{ }^{2} J=14.7 \mathrm{~Hz} ; 1.3 \mathrm{H}, \mathrm{CH}_{2}\right), 3.21\left(\mathrm{~d},{ }^{2} J=\right.$ $\left.15.2 \mathrm{~Hz} ; 0.9 \mathrm{H}, \mathrm{CH}_{2}\right), 2.24\left(\mathrm{~s}, 1.2 \mathrm{H}, \mathrm{CH}_{3}\right), 2.18\left(\mathrm{~s}, 6.4 \mathrm{H}, \mathrm{CH}_{3}\right)$, $2.15\left(\mathrm{~s}, 4.4 \mathrm{H}, \mathrm{CH}_{3}\right) .-\mathrm{MS}(\mathrm{EI}, 70 \mathrm{eV}), \mathrm{m} / z(\%): 668\left[\mathrm{M}^{+}\right](100)$, 333 (69), 669 (57), 334 (32), 303 (32), $319(28)$. - MS $\left(\mathrm{C}_{52} \mathrm{H}_{44}\right)$ : calcd. 668.34430, found 668.34399. $-\mathrm{C}_{52} \mathrm{H}_{44}$ (668.9): calcd. $\mathrm{C}$ 93.37, H 6.63; found C 89.90, H 7.49.

anti-1,2-Dimethyl 3.2$](1,4)$ naphthalenophan-1-ene (7a): The crude product is recrystallized from acetone/ethanol. White solid, yield $0.62 \mathrm{~g}(41 \%)$, m.p. $189^{\circ} \mathrm{C}$. - IR $(\mathrm{KBr}): \tilde{v}=3071 \mathrm{~cm}^{-1}, 3040$, $3010,2935,2863,1617,1587,1512,1452,1423,1389,1154,1088$, 1029, 834, 759, $-{ }^{1} \mathrm{H}$ NMR $\left(300 \mathrm{MHz}, \mathrm{CDCl}_{3}\right): \delta=7.85\left(\mathrm{~m},{ }^{3} \mathrm{~J}=\right.$ $\left.5.3,{ }^{4} J=2.0 \mathrm{~Hz} ; 2 \mathrm{H}, 5-\mathrm{H}\right), 7.74\left(\mathrm{~m},{ }^{3} J=5.0,{ }^{4} J=2.2 \mathrm{~Hz} ; 2 \mathrm{H}\right.$, $8-\mathrm{H}), 7.42\left(\mathrm{dt},{ }^{3} \mathrm{~J}=5.3,{ }^{4} \mathrm{~J}=2.0 \mathrm{~Hz} ; 2 \mathrm{H}, 6-\mathrm{H}\right), 7.39\left(\mathrm{dt},{ }^{3} J=5.4\right.$ $\left.{ }^{4} J=2.2 \mathrm{~Hz} ; 2 \mathrm{H}, 7-\mathrm{H}\right), 5.93(\mathrm{~d}, J=7.2 \mathrm{~Hz} ; 2 \mathrm{H}, 3-\mathrm{H}), 5.67(\mathrm{~d}$ $J=7.2 \mathrm{~Hz} ; 2 \mathrm{H}, 2-\mathrm{H}), 3.33\left(\mathrm{dt},{ }^{2} J=14.4,{ }^{3} J=5.8 \mathrm{~Hz} ; 2 \mathrm{H}\right.$, $\left.\mathrm{CH}_{2} \mathrm{CH}_{2} \mathrm{CH}_{2}\right), 2.66\left(\mathrm{dt},{ }^{2} \mathrm{~J}=14.1,{ }^{3} \mathrm{~J}=5.8 \mathrm{~Hz} ; 2 \mathrm{H}\right.$, $\mathrm{CH}_{2} \mathrm{CH}_{2} \mathrm{CH}_{2}$ ), 2.44 (s, $6 \mathrm{H}, \mathrm{CH}_{3}$ ), 2.17 (quint, $J=5.8 \mathrm{~Hz} ; 2 \mathrm{H}$, $\mathrm{CH}_{2} \mathrm{CH}_{2} \mathrm{CH}_{2}$ ). $-{ }^{1} \mathrm{H}$ NMR ( $\left.300 \mathrm{MHz}, \mathrm{CD}_{3} \mathrm{CD}_{2} \mathrm{Br},-90^{\circ} \mathrm{C}\right): \delta=$ $8.10+8.02(\mathrm{~m}, 2 \mathrm{H}, 5-\mathrm{H}), 7.90+7.84(\mathrm{~m}, 2 \mathrm{H}, 8-\mathrm{H}), 7.52(\mathrm{~m}, 4 \mathrm{H}$, $6 / 7-\mathrm{H}), 6.08+5.86(\mathrm{~m}, 2 \mathrm{H}, 3-\mathrm{H}), 5.78+5.60(\mathrm{~m}, 2 \mathrm{H}, 2-\mathrm{H}), 3.30$ $+3.18+3.01+2.79\left(\mathrm{~m}, 2 \mathrm{H}, \mathrm{CH}_{2} \mathrm{CH}_{2} \mathrm{CH}_{2}\right), 2.54\left(\mathrm{~d}, 6 \mathrm{H}, \mathrm{CH}_{3}\right)$, $2.26\left(\mathrm{~m}, 2 \mathrm{H}, \mathrm{CH}_{2} \mathrm{CH}_{2} \mathrm{CH}_{2}\right)$. $-\mathrm{MS}(\mathrm{EI}, 70 \mathrm{eV}), \mathrm{m} / \mathrm{z}(\%): 348\left[\mathrm{M}^{+}\right]$ (100), $179(64), 169(58), 165(50)$ - - MS $\left(\mathrm{C}_{27} \mathrm{H}_{24}\right):$ calcd. 348.18780, found 348.18789. $-\mathrm{C}_{27} \mathrm{H}_{24}$ (348.5): calcd. C 93.06, $\mathrm{H}$ 6.94; found C $92.45, \mathrm{H} 7.30$.

anti-1,2,5,15-Tetramethyl [3.2](1,4)naphthalenophan-1-ene (7b): The product is recrystallized from acetone/ethanol. Yield $0.81 \mathrm{~g}$ $(50 \%)$. Colorless crystals, m.p. $188-190^{\circ} \mathrm{C} .-\mathrm{IR}(\mathrm{KBr}): \tilde{v}=3063$ $\mathrm{cm}^{-1}, 2927,2855,1589,1504,1440,1027,876,753 .-{ }^{1} \mathrm{H}$ NMR $\left(300 \mathrm{MHz}, \mathrm{CDCl}_{3}\right): \delta=7.93(\mathrm{dd}, J=8.0 \mathrm{~Hz} ; 2 \mathrm{H}, 5-\mathrm{H}), 7.72(\mathrm{dd}$, $\left.{ }^{3} J=7.9,{ }^{4} J=1.3 \mathrm{~Hz} ; 2 \mathrm{H}, 8-\mathrm{H}\right), 7.35\left(\mathrm{dt},{ }^{3} J=8.7,{ }^{4} J=1.0 \mathrm{~Hz}\right.$; $2 \mathrm{H}, 6 / 7-\mathrm{H}), 7.29\left(\mathrm{dt},{ }^{3} \mathrm{~J}=8.8,{ }^{4} \mathrm{~J}=1.2 \mathrm{~Hz} ; 2 \mathrm{H}, 6 / 7-\mathrm{H}\right), 5.81(\mathrm{~s}$, $2 \mathrm{H}, 3-\mathrm{H}), 3.30\left(\mathrm{dt},{ }^{2} \mathrm{~J}=15.0,{ }^{3} \mathrm{~J}=6.1 \mathrm{~Hz} ; 2 \mathrm{H}, \mathrm{CH}_{2} \mathrm{CH}_{2} \mathrm{CH}_{2}\right)$, $2.94\left(\mathrm{dt},{ }^{2} \mathrm{~J}=14.7,{ }^{3} \mathrm{~J}=5.9 \mathrm{~Hz} ; 2 \mathrm{H}, \mathrm{CH}_{2} \mathrm{CH}_{2} \mathrm{CH}_{2}\right), 2.44(\mathrm{~s}, 6 \mathrm{H}$, 
$\mathrm{CH}_{3}$ allyl), 2.25 (quint, $J=5.8 \mathrm{~Hz} ; 2 \mathrm{H}, \mathrm{CH}_{2} \mathrm{CH}_{2} \mathrm{CH}_{2}$ ), 1.57 (s, $6 \mathrm{H}, \mathrm{CH}_{3}$ aromat). - MS (EI, $\left.70 \mathrm{eV}\right), \mathrm{m} / z(\%): 376\left[\mathrm{M}^{+}\right](100), 193$ (19). - MS $\left(\mathrm{C}_{29} \mathrm{H}_{28}\right)$ : calcd. 376.21910, found 376.22012. $-\mathrm{C}_{29} \mathrm{H}_{28}$ (376.5): calcd. C 92.50, H 7.50; found C 91.69, H 7.50.

Photocyclization of $6 \mathrm{a}: 30.4 \mathrm{mg}(47.6 \mu \mathrm{mol})$ of $6 \mathrm{a}$ and a catalytic amount of iodine are dissolved in $5 \mathrm{ml}$ of dry cyclohexane, and the solution is irradiated with UV light for $20 \mathrm{~h}$ in a stream of air. After evaporation of the solvent the residue is purified by thin-layer chromatography (eluant petroleum etherlethyl acetate, $5: 1$ ) to yield a mixture of anti- (8a) and syn-1,2,20,21-tetramethyl[1.1](5,8) piceno [2] $(1,4)$-naphthalenophan-1-ene $(\mathbf{8 b})$ in small amounts. Colorless crystals, m.p. $139^{\circ} \mathrm{C}$. - IR (KBr): $\tilde{v}=3071 \mathrm{~cm}^{-1}, 2927$, 2856, 1678, 1592, 1511, 1445, 1390,1165, 1087, 1025, 846, 797, 757. $-{ }^{1} \mathrm{H}$ NMR $\left(300 \mathrm{MHz}, \mathrm{CDCl}_{3}\right): \delta=8.52(\mathrm{dd}, J=7.6 \mathrm{~Hz}$; $2 \mathrm{H}$, naphthaleno $5 / 8-\mathrm{H}$, piceno $1 / 4 / 9 / 12-\mathrm{H}), 8.35$ (t, $J=8.0 \mathrm{~Hz}$; $2 \mathrm{H}$, naphthaleno $5 / 8-\mathrm{H}$, piceno $1 / 4 / 9 / 12-\mathrm{H}), 8.17+8.05(2 \mathrm{~d}, J=$ $8.4 \mathrm{~Hz} ; 2 \mathrm{H}$, naphthaleno $1 / 4-\mathrm{H}$, piceno $1 / 4 / 9 / 12-\mathrm{H}), 7.68-7.56(\mathrm{~m}$; $6 \mathrm{H}$, naphthaleno $5 / 8-\mathrm{H}$, piceno $1 / 2 / 3 / 4 / 9 / 10 / 11 / 12-\mathrm{H}), 7.45\left(\mathrm{t},{ }^{3} J=\right.$ $7.6 \mathrm{~Hz} ; 2 \mathrm{H}$, naphthaleno $7-\mathrm{H}), 7.35$ (AB system, ${ }^{3} \mathrm{~J}=7.1 \mathrm{~Hz}$; $1.3 \mathrm{H}$, syn-naphthaleno $2 / 3-\mathrm{H}), 7.19\left(\mathrm{t},{ }^{3} J=7.2 \mathrm{~Hz} ; 1.4 \mathrm{H}\right.$, antinaphthaleno 6-H), $7.11\left(\mathrm{t},{ }^{3} J=7.4 \mathrm{~Hz} ; 0.7 \mathrm{H}\right.$, syn-naphthaleno 6$\mathrm{H}$ ), 7.00 (AB system, ${ }^{3} J=7.1 \mathrm{~Hz} ; 2.7 \mathrm{H}$, anti-naphthaleno $2 / 3-\mathrm{H}$ ), $6.83(\mathrm{~s}, 2 \mathrm{H}$, piceno $6-\mathrm{H}), 5.06\left(\mathrm{~d},{ }^{3} J=17.2 \mathrm{~Hz} ; 2 \mathrm{H}, \mathrm{CH}_{2}\right), 4.42+$ $4.34\left(2 \mathrm{~d},{ }^{3} \mathrm{~J}=17.4 \mathrm{~Hz} ; 2 \mathrm{H}, \mathrm{CH}_{2}\right), 2.91$ (s; $6 \mathrm{H}$, aromatic $\mathrm{CH}_{3}$ ), 2.49 (s; $2 \mathrm{H}$, olefinic $\left.\mathrm{CH}_{3}\right), 2.44$ (s, $4 \mathrm{H}$, olefinic $\mathrm{CH}_{3}$ ). - MS (EI, $70 \mathrm{eV}), m / z(\%): 638\left[\mathrm{M}^{+}\right](100), 639(55), 640(53), 641$ (24), 303 (18), 318 (18), 289 (15). - MS $\left(\mathrm{C}_{50} \mathrm{H}_{38}\right)$ : calcd. C 638.29735, found 638.29858 .
* Dedicated to Professor E. V. Dehmlow on the occassion of his 60 th birthday.

[1] J. H. Wood, J. A. Stanfield, J. Am. Chem. Soc. 1942, 64, 2343-2344.

[2] [2a] P. M. Keehn, S. M. Rosenfeld (Eds.), Cyclophanes, Academic Press, New York, 1983, vol. 1 and 2.- [2b] F. Vögtle, CyclophanChemie, Teubner, Stuttgart, 1990.

[3] F. Vögtle, Supramolekulare Chemie, Teubner, Stuttgart, 1989.

[4] [4a] H.-F. Grützmacher, E. Neumann, F. Ebmeyer, K. Albrecht, P. Schelenz, Chem Ber 1989,122,2291-2297 - [4b] H.F. Grützmacher, E. Neumann, Chem. Ber. 1993, 126, 1495-1497. - [4c] H.-F. Grützmacher, A. Mehdizadeh, A. Mülverstedt, Chem. Ber. 1994, 127, 1163-1166; following paper.

[5] [sa] J. E. McMurry, M. P. Fleming, K. L. Kees, L. R. Krepski, J. Org. Chem. 1978, 43, 3255-3266. - [5b] J. E. McMurry, Acc. Chem. Res. 1983, 16, 405-411.

[6] J. E. McMurry, G. J. Haley, J. R. Matz, J. C. Clardy, G. V. Duyne. J. Am. Chem. Soc. 1984, 106, 5018-5019.

[7] [7a] R. H. Mitchell. S. A. Weerawana, Tetrahedron Lett. 1986, 27, 453-456, - ${ }^{[76]}$ D. Tanner, O. Wennerström, Acta Chem. Scand., Ser. B, 1983, 37, 693-698.

[8] [8a] J. Schmidlin. P. Massini, Ber. Dtsch. Chem. Ges. 1909, 42, 2377-2392. - [8b] F. F. Blicke, J. Am. Chem. Soc. 1927, 49, $2843-2849$

[9] E. A. Chandross, C. J. Dempster, J. Am. Chem. Soc. 1970, 92, 3586-3593.

[10] T. Wismonski-Knittel, G. Fischer, E. Fischer, J. Chem. Soc., Perkin Trans. 2, 1974, 1930-1940.

[11] H. Hopf, C. Mlynek, S. El-Tamany, L. Ernst, J. Am. Chem. Soc. $1985,107,6620-6627$.

${ }^{[12]}$ A. M. Khaletzky, A. Ya. Kaplan, Russ. J. Gen. Chem. 1956, $26,873-876$.

[13] F. F. Blicke, R. F. Feldkamp, J. Am. Chem. Soc. 1944, 66, 1087-1091.

[14] P. Belliard, E. Marechal, Bull. Soc. Chim. Fr. 1972, 4255-4275.

${ }^{[15]}$ J. E. McMurry, K. L. Kees, J. Org. Chem. 1977, 42, 2655-2656.

[390/93] 